\title{
HUBUNGAN ANTARA DUKUNGAN EMOSIONAL DENGAN KEPATUHAN DIET LANSIA PENDERITA HIPERTENSI
}

\author{
THE CORRELATION OF EMOTIONAL SUPPORT AND ELDERLY DIET \\ COMPLIANCE WITH HYPERTENSION
}

\author{
Dita Rahmatika \\ Departemen Gizi Kesehatan \\ Fakultas Kesehatan Masyarakat, Universitas Airlangga, Surabaya, Indonesia \\ Alamat Korespondensi: Dita Rahmatika \\ Email:rcriantika@gmail.com
}

\begin{abstract}
Hypertension is a condition where a person's blood pressure reaches 140/90 mmHg. Hypertension is the silent disease that causes death in Indonesia. Elderly people mostly suffer from hypertension. This study aims to investigate the correlation of emotional support and dietary compliance of elderly patients with hypertension around the area of Sukomulyo Community Health Center, Manyar subdistrict, Gresik. This study was an observational analytical research, based on the data collection. This research employed a cross sectional method. The samples used simple random sampling with a sample size of 37 respondents who were elderly patients with hypertension. The respondents' characteristics were mostly female with the age criteria of 60- 70 years old, and working as housewives. Meanwhile, the characteristics based on education level suggested that more than half of the respondents were high school graduates. Almost all respondents got emotional support with good category (83.8\%), and most respondents were quite obedient in doing diet reaching 67.6\%. The result of statistical test of the correlation between emotional support and the adherence of elderly diet of hypertension show a p-value of 0.552. There is no correlation between family emotional support and the compliance of elderly diet in hypertensive patients in the integrated health post of elderly in the working area of Sukomulyo Community Health Center. The elderly's family is expected to provide more attention to the elderly to be obedient in having the hypretensive diet.
\end{abstract}

Keywords: emotional support, hypertension, dietary compliance, elderly

\begin{abstract}
ABSTRAK
Hipertensi adalah suatu keadaan dimana tekanan darah seseorang diatas normal yaitu (120/80 $\mathrm{mmHg})$. Hipertensi merupakan penyakit the silent disease dan menyebabkan kematian tertinggi di Indonesia. Hipertensi sebagian besar diderita oleh orang dengan usia lanjut. Tujuan dari penelitian ini mengetahui hubungan antara dukungan emosional dengan kepatuhan diet pada lansia penderita hipertensi di wilayah kerja Puskesmas Sukomulyo Kecamatan Manyar Kabupaten Gresik. Penelitian ini merupakan penelitian observasional analitik, berdasarkan waktu pengumpulan datanya penelian ini bersifat cross sectional. Pengambilan sampel menggunakan teknik simple random sampling dengan besar sampel sebanyak 37 responden yaitu lansia penderita hipertensi. Karakteristik responden berdasarkan jenis kelamin bahwa sebagian besar responden berjenis perempuan yaitu sebesar 54\% dengan kriteria umur 60-70 tahun serta pekerjaan mayoritas responden adalah Ibu Rumah Tangga. Sementara karakteristik berdasarkan tingkat pendidikan lebih dari separuh responden Tamat SMA. Hampir seluruh responden mendapatkan dukungan emosional dengan kategori baik yaitu sebesar $83,8 \%$ serta sebagian besar responden cukup patuh dalam melakukan diet yaitu sebesar 67,6\%. Hasil uji statistik hubungan antara dukungan emosional dengan kepatuhan diet lansia penderita hipertensi menunjukkan $\mathrm{p}=0,552$ yang menunjukkan bahwa tidak ada hubungan antara dukungan emosional keluarga dengan kepatuhan diet lansia pada penderita hipertensi di Posyandu Lansia Wilayah Kerja Puskesmas Sukomulyo. Bagi keluarga diharapkan memberikan perhatian lebih pada lansia yang ada dikeluarganya agar patuh dalam melakukan diet hipertensi.
\end{abstract}

Kata kunci: dukungan emosional, hipertensi, kepatuhan diet, lansia

\section{PENDAHULUAN}

Tekanan darah diatas 140/90 mmHg maka disebut Hipertensi. Hipertensi merupakan penyakit the silent disease dan menyebabkan kematian tertinggi di Indonesia (Tumenggung, 2013). Penyakit hipertensi telah membunuh 9,4 juta warga dunia setiap tahunnya. Ada satu miliar orang yang terkena hipertensi, dan akan terus meningkat seiring jumlah penduduk yang 
membesar. Persentase penderita hipertensi saat ini paling banyak terdapat di negara berkembang (WHO, 2011). Prevalensi hipertensi di Indonesia sebesar $31,7 \%$ berdasarkan hasil Riskesdas (2013) dan di Provinsi Jawa Timur sebesar 37,4\%. Penyakit degeneratif sering ditemukan pada usia lanjut atau lansia misalnya penyakit jantung koroner (PJK), diabetes melitus, reumatik, kanker dan salah satu penyakit yang paling sering diderita adalah hipertensi (Darmojo, 2010). diperkirakan tahun 2025 terjadi peningkatan penderita hipertensi mencapai 1,6 miliar orang di Dunia, khususnya pada lansia yaitu mengalami peningkatan sebesesar 1,2 miliar jiwa (Bandiyah, 2009).

Peningkatan tekanan darah sejalan dengan bertambahnya umur seseorang. Tekanan darah sistolik akan terus meningkat sampa pada umur 80 tahun dan tekkanan diastolic akan terus meningkat sampai usia 55-60 tahun. Walau mengalami pningkatan pada akhirnya baik sistolik maupun diastolik akan cenderung menurun secara bertahap. Prevalensi hipertensi di Cina menunjukkan peningkatan dalam beberapa tahun terakhir (Jiang, 2016). Cara mencegah hipertensi bisa dilakukan dengan mempertahanlan berat badan, menurunkan kadar kolestrol, mengurangi konsumsi garam, diet tinggi serat, mengkonsumsi buah - buahan dan sayuran serta menjalankan hidup secara sehat (Ridwan, 2002). Upaya lain yang sangat dibutuhkan oleh penderita hipertensi adalah support systemutamanya dari keluarga (Ridwan, 2002). Rendahnya kesadaran keluarga untuk memberikan dukungan kepada lansia untuk memeriksakan tekanan darahnya secara rutin dan memiliki pola makan yang tidak sehat serta kurangnya olahraga memicu terjadinya peningkatan kasus hipertensi (Hamid, 2013)

Dukungan sosial adalah suatu keadaan dimana seorang individu tersebut memperoleh keadaan yang bermanfaat dari orang yang dipercayai sehingga individu tersebut tau bahwa dirinya diperhatikan, dihargai dan dicintai. (Setiadi, 2008) Selain itu, dukungan sosial juga dikatakan suatu hubungan interpersonal yang memberikan dukungan emosional, persahabatan dan bantuan. (Pender dan Murdaugh 2002).

Individu banyak memperoleh dukungan sosial dari lingkungan sekitar. Sistem dukungan natural, sistem dukungan teman sebaya, sistem dukungan organisasi keagamaan, sistem dukungan organisasi tenaga professional, kelompok dukungan yang tidak langsung dengan tenaga professional merupakan beberapa sistem dukungan sosial yang berkaitan dengan kesehatan. Namun dukungan dari keluarga (dukungan system natural) tetap merupakan kelompok dukungan yang utama. Dukungan keluarga adalah sebagai suatu proses hubungan antara keluarga dengan lingkungan sosial (Setiadi, 2008).

Bentuk dukungan bagi penderita hipertensi salah satunya adalah berupa dukungan emosional. Dukungan emosional antara lain berupa merawat lansia dengan penuh kasih sayang dan simpati, rasa aman, memberikan semangat, membangkitkan atas keputusasaan, mengurangi rendah diri serta mengurangi keterbatasan akibat ketidak mampuan fisik yang dialami (Nugroho, 2000). Membantu dan merawat lansia dengan penuh kasih sayang, menunjukkan wajah yang menyenangkan saat membantu atau melayani lansia, tidak membiarkan lansia sendiri saat menghadapi masalah merupakan bentuk lain dari dukungan emosional yang dapat diberikan terhadap lansia dengan hipertensi (Zulkifli, 2006).

Puskesmas Sukomulyo Kecamatan Manyar didapatkan angka kejadian hipertensi [ada lansia sejumlah 1464 orang lansia pada tahun 2014 dan pada tahun 2015 terjadi peningkatan menjadi 3861 lansia. Dari hasil wawancara kepada lansia dengan hipertensi didapatkan keterangan bahwa mereka masih mengkonsumsi gorengan, ikan asin, dan jeroan. Demikian juga aktifitas fisik mereka seperti jalan kaki atau senam jarang dilakukan. Hal ini 
menyebabkan mereka mengalami kenaikan tekanan darah disamping faktor usia. Dalam penanganan penderita hipertensi diperlukan adanya dukungan dar keluarga salah satunya berupa dukungan emosional. Tujuan dari penelitian ini adalah untuk mengetahui hubungan antara dukungan emosional dengan kepatuhan diet pada lansia penderita hipertensi di wilayah kerja Puskesmas Sukomulyo Kecamatan Manyar Kabupaten Gresik.

\section{METODE PENELITIAN}

Penelitian ini merupakan penelitian observasional analitik, berdasarkan waktu pengumpulan datanya penelian ini bersifat cross sectional. Pengambilan sampel menggunakan teknik pencuplikan acak sederhana dengan besar sampel sebanyak 37 responden yaitu lansia penderita hipertensi. Pengambilan data dilakukan pada Bulan Oktober - November 2016. Karakteristik penelitian antara lain umur, jenis kelamin dan tingkat pendidikan. Penelitian ini dilakukan Di Puskesmas Sukomulyo Gresik. Kuisioner karakteristik dan kuisioner dukungan keluarga yang diadaptasi dari kuisioner hubungan dukungan keluarga dan self care managementlansia dengan hipertensimerupakan instrumen yang digunakan dalam penelitian. Variabel dukungan emosional diperoleh melalui wawancara menggunakan kuisioner sebanyak 4 pertanyaan dengan kriteria nilai: selalu skor 4, sering skor 3, jarang skor 2 dan tidak pernah skor 1 . Variabel kepatuhan diet diperoleh menggunakan kuisioner dengan klasifikasi patuh jika responden mengkonsumsi lebih dari sama dengan $75 \%$ makanan yang dianjurkan \& kurang dari sama dengan $10 \%$ makanan yang tidak dianjurkan, tidak patuh jika responden mengkonsumsi kurang dari sama dengan $75 \%$ makanan yang dianjurkan dan lebih dari sama dengan $10 \%$ makanan yang tidak dianjurkan.

Analisis data disajikan dalam bentuk tabel distribusi frekuensi, tabulasi silang serta persentase. Untuk mengetahui hubungan dukungan emosional dengan kepatuhan diet pada lansia dilakukan dengan uji spearman dengan derajat kemaknaan $(\alpha) 0,05$. Hasil penelitian ini dikatakan bermakna jika hasil p kurang dari sama dengan 0,05 yang artinya ada hubungan antara dukungan emosional dengan kepatuhan diet pada lansia penderita hipertensi. Penelitian ini telah lolos kaji etik dengan No: 636-KEPK dari Komisi Etik Penelitian Kesehatan Fakultas Kesehatan Masyarakat Universitas Airlangga.

\section{HASIL}

Puskesmas Sukomulyo merupakan Unit Pelaksana Teknis (UPT) dari Dinas Kesehatan Kabupaten Gresik. 3 besar masalah kesehtaan yang banyak diderita oleh lansia di Posyandu Lansia Puskesmas Sukomulyo yaitu hipertensi sebesar 1,87\%, myalgia sebesar $20,4 \%$ dan ISPA $16 \%$.

\section{Karakteristik responden}

Berikut ini merupakan gambaran karakteristik lansia penderita hipertensi berdasarkan jenis kelamin di Posyandu wilayah kerja Puskesmas Manyar. Berdasarkan Tabel 1 diketahui bahwa sebagian besar responden (54\%) berjenis kelamin perempuan yaitu sebanyak 20 orang. Sedangkan responden yang berjenis kelamin laki-laki sebesar $46 \%$.

Tabel 1.Distribusi Karakteristik Lansia Penderita Hipertensi Berdasarkan Jenis Kelamin di Posyandu Wilayah Kerja Puskesmas Sukomulyo Tahun 2016.

\begin{tabular}{lll}
\hline Jenis Kelamin & N & \% \\
\hline Laki - laki & 17 & 46 \\
\hline Perempuan & 20 & 54 \\
\hline Total & 37 & 100 \\
\hline
\end{tabular}

Karakteristik responden berdasarkan umur dalam penelitian dikategorikan menurut Undang-Undang 
No.13 Tahun 1998 yang selanjutnya dijelaskan dalam tabel di bawah ini:

Tabel 2. Distribusi Karakteristik Lansia Penderita Hipertensi Berdasarkan Umur di Posyandu Wilayah Kerja Puskesmas Sukomulyo Tahun 2016.

\begin{tabular}{lll}
\hline Umur & $\mathbf{N}$ & $\mathbf{\%}$ \\
\hline $60-70$ & 31 & 83,8 \\
Tahun & & \\
\hline$>70$ Tahun & 6 & 16,2 \\
\hline Total & 37 & 100 \\
\hline
\end{tabular}

Tabel 2 menunjukkan hampir seluruh responden berusia 60-70 Tahun yaitu sebesar $83,3 \%$. Dalam penelitian ini juga ditemukan responden dengan umur kurang dari 70 Tahun yaitu sebanyak 6 orang dengan persentase $16,2 \%$. Karakteristik responden lainnya adalah berdasarkan pekerjaan responden yang dijelaskan dalam gambar dibawah ini:

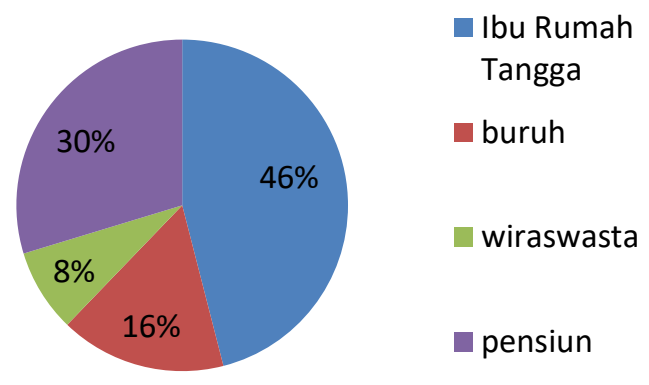

Gambar 1. Karakteristik responden berdasarkan pekerjaan.

Berdasarkan Gambar 1 dapat dilihat bahwa jenis pekerjaan yang paling banyak dimiliki oleh responden adalah ibu rumah tangga yaitu sebesar $46 \%$. Karakteristik responden terakhir adalah tingkat pendidikan yang dijelaskan dalam gambar dibawah ini:

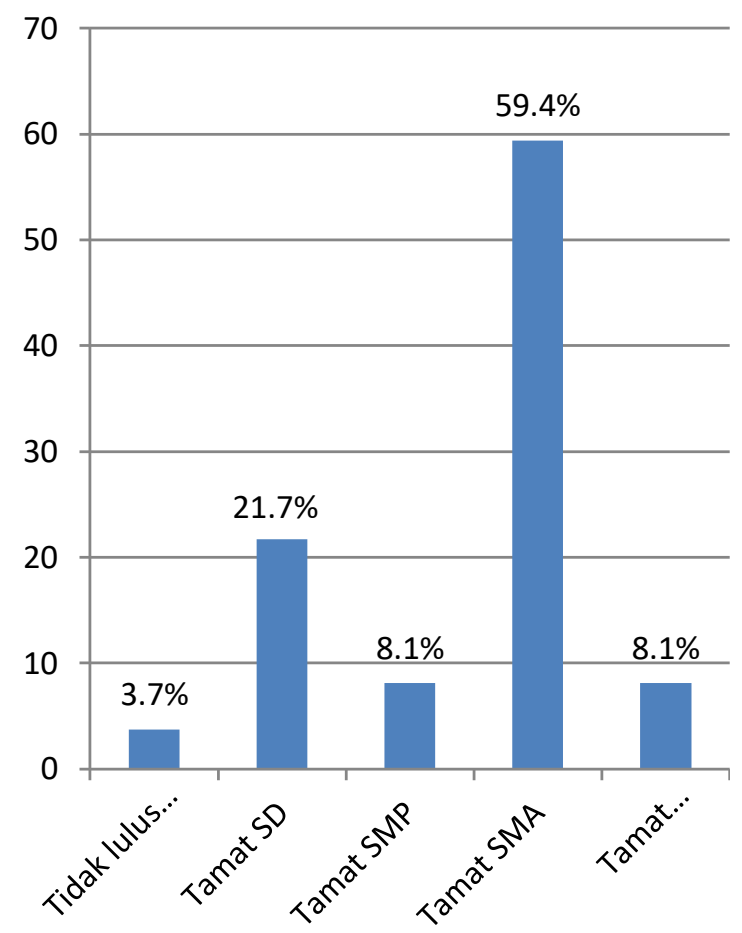

Gambar 2. Karakteristik

responden berdasarkan tingkat pendidikan.

Pada Gambar 2 diketahui bahwa sebagian besar tingkat pendidikan responden adalah tamat SMA yaitu sebesar $59,4 \%$. Tingkat pendidikan paling sedikit yang dimiliki oleh responden adalah tidak lulus SD yaitu sebesar 3,7\%.

\section{Dukungan Emosional}

Dukungan emosional dalah dukungan yang diberikan keluarga dalam bentuk perhatian, kasih sayang dan simpati. Dalam penelitian ini pengambilan data dilakukan dengan menggunakan kuisioner. Kriteria penelitian untuk dukungan emosional dijelaskan dalam tabel dibawah ini:

Tabel 3. Kriteria Penilaian Jawaban Responden.

\begin{tabular}{cc}
\hline Jawaban & Skor \\
\hline Tidak pernah & 1 \\
Jarang & 2 \\
Sering & 3 \\
Selalu & 4 \\
\hline
\end{tabular}


Skor total jawaban responden mengenai dukungan emosional adalah 16. Dalam penelitian ini interpretasi dukungan emosional dikategorikan menjadi 3, yaitu baik jika skor 12-16, cukup jika skor 8-12 dan kurang jika skor 4-7. Pada bagian ini disajikan hasil persentase dukungan emosional responden yaitu sebagai berikut:

Tabel 4.Persentase dukungan emosional pada lansia penderita hipertensi di Posyandu wilayah kerja Puskesmas Sukomulyo Tahun 2016.

\begin{tabular}{ccc}
\hline Kategori & n & \% \\
\hline Baik & 31 & 83,8 \\
Cukup & 6 & 16,2 \\
Kurang & 0 & 0 \\
\hline Total & 37 & 100 \\
\hline
\end{tabular}

Tabel 5. Klasifikasi penilaian kepatuhan diet.

\begin{tabular}{ll}
\hline \multicolumn{1}{c}{ Kategori } & \multicolumn{1}{c}{ Keterangan } \\
\hline Patuh & jika responden mengkonsumsi $\geq 75 \%$ makanan yang dianjurkan \\
& dan $\leq 10 \%$ makanan yang tidak dianjurkan. \\
\hline Tidak patuh & jika responden mengkonsumsi $\leq 75 \%$ makanan dianjurkan dan \\
& $\geq 10 \%$ makanan yang tidak dianjurkan. \\
\hline
\end{tabular}

Tabel 6. Kepatuhan Diet Lansia Penderita Hipertensi di Posyandu Lansia wilayah kerja Puskesmas Sukomulyo Tahun 2016.

\begin{tabular}{ccc}
\hline Kepatuhan diet & n & \% \\
\hline Tidak patuh & 11 & 29,7 \\
Patuh & 26 & 70,3 \\
\hline Total & 37 & 100
\end{tabular}

Berdasarkan Tabel 6 dapat diketahui distribusi lansia dengan hipertensi di Posyandu lansia wilayah kerja Puskesmas Sukomulyo. Sebanyak 70,3\% mematuhi diet.

\section{Hubungan Dukungan Emosional dengan kepatuhan diet.}

Tabel dibawah ini merupakan hasil dari uji spearman
Pada Tabel 4 dapat dilihat bahwa hampir seluruh responden mendapatkan dukungan emosional dengan kategori baik yaitu sebesar 83,8\%.

\section{Kepatuhan Diet}

Kepatuhan diet merupakan tindakan atau perilaku kepatuhan untuk mentaati diet rendah garam pada penderita hipertensi. Pada bagian ini disajikan hasil persentase kepatuhan diet pada lansia penderita hipertensi. Hasil tersebut didapat dari wawancara dengan lansia menggunakan kuisioner pola konsumsi makanan yang dianjurkan dan makanan yang tidak dianjurkan untuk dikonsumsi oleh lansia penderita hipertensi.

Data diambil melalui wawancara dengan bantuan kuisioner dengan klasifikasi sebagai berikut: 
Tabel 7. Hubungan Antara Dukungan Emosional Dengan Kepatuhan Diet Lansia Penderita Hipertensi Di Posyandu Lansia Wilayah Kerja Puskesmas Sukomulyo Tahun 2016.

Kepatuhan diet

\begin{tabular}{ccccccc}
$\begin{array}{c}\text { Duku-ngan emo- } \\
\text { sional }\end{array}$ & \multicolumn{2}{c}{ Tidak patuh } & \multicolumn{2}{c}{ Patuh } & \multicolumn{2}{c}{ Total } \\
\cline { 2 - 6 } & $\mathbf{n}$ & $\mathbf{\%}$ & $\mathbf{n}$ & $\mathbf{\%}$ & $\mathbf{n}$ & $\mathbf{\%}$ \\
\hline Kurang & 0 & 0 & 0 & 0 & 0 & 0 \\
\hline Sedang & 1 & 3 & 5 & 13 & 6 & 16 \\
\hline Baik & 10 & 27 & 21 & 57 & 31 & 84 \\
\hline \multicolumn{8}{c}{ Spearmen Rho } & $\mathrm{p}=0,552$ & \\
\hline
\end{tabular}

\section{PEMBAHASAN}

\section{Karakteristik}

Berdasarkan hasil penelitian karakterisitik responden menunjukkan bahwa sebagian besar responden berjenis kelamin perempuan yaitu sebanyak $54 \%$. Penyakit hipertensi dikategorikan sebagai the silent disease karena penderita tidak mengetahui dirinya mengidap hipertensi sebelum memeriksakan tekanan darah. wanita menopause lebih rentan terkena penyakit kardiovaskuler dibandingkan wanita sebelum menopause dikemukakan oleh Nuraini (2015), karena peran hormon eksterogen dalam peningkatan kadar High Density Lipoprotein (HDL) mengalami penurunan. Kadar HDL yang tinggi ini merupakan pemicu terjadinya proses aterossklerosis. Hal ini didukung oleh penelitian Faisal et.al (2012), dalam penelitiannya menyebutkan bahwa wanita lebih rentan mengalami hipertensi dipengaruhi lingkungan pekerjaannya yang tidak sehat, pekerjaan yang menjenuhkan, dan berulang-ulang, serta masalah yang bersumber dari kehidupan rumah tangga dapat menyebabkan timbulnya hipertensi. Dalam hal ini faktor psikologis memainkan peranan yang besar karena penyakit dapat muncul dari konflik mental yang terjadi baik di lingkungan pekerjaan maupun tempat tinggal. Hal ini didukung oleh penelitian Fitriani (2012), mengemukakan bahwa di kota-kota besar seperti Jakarta, wanita dengan sosial ekonomi rendah banyak berkumpul pada Lembaga Masyarakat seperti majelis taklim.
Sebagian besar mereka mempunyai pola hidup sedenter yang ditandai dengan aktivitas fisik rendah dan pola makan yang tidak sehat, sehingga meningkatkan risiko keterpaparan terhadap hipertensi.

Berdasarkan hasil penelitian pada responden diketahui sebagian besar berusia 60-70 tahun sebanyak 83,8\%. Hipertensi erat kaitannya dengan umur, semakin tua seseorang semakin besar risiko terserang hipertensi. Hal ini sesuai dengan penelitian yang dilakukan oleh Siringoringo, et. al (2013), yang mengungkapkan terdapat hubungan yang bermakna antara umur dengan kejadian hipertensi pada kelompok usia 45-59 tahun dengan kelompok usia 60-74 tahun. Rasio prevalensi kejadian hipertensi pada kedua kelompok tersebut adalah 0,734 artinya lansia pada kelompok usia 60-74 tahun memilki risiko lebih besar mengalami hipertensi dibandingkan kelompok umur 45-59 tahun. Hal ini didukung oleh Dafey (2003), bahwa tekanan darah secara alami cenderung meningkat seiring bertambahnya usia.

Menurut Nina (2007), pada usia lanjut secara fisiologis dapat dilihat bahwa tekanan darahnya cenderung tinggi. Hal ini dapat terjadi karen adanya pengurangan aktifitas di usia senja. Kondisi ini juga diperkuat dengan adanya penebalan dinding arteri lansia serta kakunya dinding arteri karena adanya arterioklorosis sehingga darah dipaksa untuk melalui pembuluh darah yang sempit daripada biasanya. Hal ini akan menyebabkan peningkatan darah pada lansia.

Berdasarkan penelitian yang dilakukan oleh Anggara dan Prayitno 
(2013), diketahui bahwa pekerjaan memiliki hubungan terhadap peningkatan tekanan darah dengan nilai $(p=0,00)$. Pekerjaan memiliki pengaruh terhadap aktifitas fisik seseorang dengan bekerja maka diharapkan orang tersebut memiliki aktifitas fisik lebih banyak jika dibandingkan orang yang tidak bekerja. Pada orang yang tidak bekerja terjadi peningkatan resiko hipertensi karena aktfitas fisiknya sedikit. Demikian juga dengan orang yang tidak aktif karenacenderung mempunyai frekuensi denyut jantung yang lebih tinggi sehingga otot jantungnya bekerja lebih keras pada setiap kontraksi. Besarnya tekanan tekanan yang dibebankan pada arteri disebabkan oleh semakin keras dan semakin sering otot jantung bekerja. (Aris, 2007).

Sebagian besar lansia yang menderita hipertensi pada penelitian ini $(46 \%)$ bekerja sebagai ibu rumah tangga (IRT). Dimana risiko menderita hipertensi pada IRT lebih tinggi, hal ini disebabkan oleh kurangnya aktivitas fisik seperti olahraga. Kebanyakan IRT melakukan rutinitas yang sama setiap hari sehingga membuat suntuk. Kesibukan yang dimulai dari pagi sampai malam hari untuk mengurusi kebutuhan keluarga membuat IRT jarang melakukan olahraga, padahal olaharga adalah salah satu cara pencegahan terjadinya hipertensi pada usia lanjut (Agrina, 2011).

Pendidikan merupakan salah satu faktor yang paling penting untuk menentukan perilaku seseorang. Pendidikan merupakan salah satu usaha pengorganisasian masyarakat sebagai salah satu langkah untuk meningkatkan derajat kesehatan. Pendidikan diharapkan dapat digunakan sebagai dasar untuk mempengaruhi seseorang agar melakukan perubahan perilaku pada dirinya. Semakin tinggi tingkat pendidikan seseorang semakin mudah pula penerimaan informasi kesehatan. Sebaliknya jika pendidikan seseorang rendah maka penerimaan informasi kesehatan dan nilai - nilai baru yang diperkenalkan padanya akan terhambat (Irawati dan Wahyuni 2011).

Menurut gambar 2 dapat dilihat bahwa sebagian besar lansia dengan hipertensi memiliki tingkat pendidikan tamat SMA yaitu sebesar $61 \%$. Penemuan dalam penelitian ini sesuai dengan penelitian Murti dan Rebecca (2014), bahwa tingkat pendidikan berhubungan signifikan dengan hipertensi pada lansia di kabupaten Sukoharjo. Lansia dengan pendidikan SMP atau SMU mempunyai risiko 1/5 lebih kecil mengalami hipertensi dibandingkan dengan yang berpendidikan SD atau tidak sekolah sedangkan lansia berpendidikan PT mempunyai risiko 1/10 kali lebih kecil untuk mengalami hipertensi dibandingkan dengan berpendidikan SD atau tidak sekolah.

\section{Dukungan Emosional}

Perhatian, kasih sayang dan empati merupakan bentuk dari dukungan emosional dalam keluarga. Dukungan emosional merupakan fungsi afektif keluarga yang memiliki fungsi internal dalam memenuhi kebutuhan psikososial anggota keluarga melalui rasa saling mengasuh, cinta kasih, kehangatan dan saling mendukung serta menghargai antar anggota keluarga. Penderita hipertensi yang mendapatkan dukungan dari keluarga akan memudahkan pasien dalam menghadapi penyakit yang dideritanya karna dia merasa tidak perlu menanggung beban sendiri akan tetapi masih ada orang lain yang memperhatikan, mendengarkan, simpati dan empati. Bahkan diharapkan keluarga dapat membantu memecahkan masalah yang dihadapinya. (Friedman, 2010).

Menurut Niven (2008), dukungan emosional merupakan salah satu mekanisme dukungan keluarga dalam bentuk nyata. Keadaan stress dapat mengurangi perasaan seseorang akan hal dimiliki dan dicintai. Dukungan emosional diharapkan dapat menggantikan dan menguatkan perasaan ini. Dukungan 
emosional oleh keluarga sebagai sebuah tempat yang aman dan damai serta pemulihan penguasaan emosi yang meliputi ungkapan empati, kepedulian dan perhatian. Dalam penelitian diketahui bahwa hampir seluruh responden memilki dukungan emosional dengan kategori baik dari keluarganya yaitu sebesar $83,8 \%$. Hasil berbeda diungkapkan oleh Nisfiani (2014) bahwa sebagian besar responden $(64,8 \%)$ mendapat dukungan keluarga kurang. Dukungan keluarga yang kurang ini menunjukkan kurangnya bantuan keluarga dalam bentuk informasi, finansial, emosi serta penghargaan. Bentuk dukungan emosional dalam penelitian ini adalah berupa perhatian keluarga dalam merawat dan mendengarkan keluhan lansia serta mengingatkan untuk makan makanan sehat setiap hari. Bentuk lainnya adalah menunjukkan wajah yang menyenagkan saat membantu dan melayani lansia.

\section{Kepatuhan Diet}

Menurut kamus umum bahasa Indonesia patuh dapat diartikan sebagai suka dan taat pada ajaran atau perintah serta disiplin. Sedangkan kepatuhan dapat diartikan sebagai sifat patuh terhadap peraturan atau saran (anjuran) yang diberikan pada seseorang tersebut (Hasan, 2008). Pendapat yang hampir sama diungkapkan oleh Notoatmodjo (2008), bahwa kepatuhan merupakan suatu perubahan perilaku dari perilaku yang dinilai tidak mentaati peraturan ke perilaku yang mentaati peraturan. Dan dapat dilihat dari kepatuhan seseorang dalam melaksanakan suatu aturan atau perilaku yang disarankan oleh pihak lain kepadanya.

Menurut Notoatmodjo (2008), terdapat beberapa faktor yang mendukung sikap patuh seseorang. Faktor pendukung pertama adalah pendidikan, pendidikan merupakan suatu usaha manusia untuk memprolejh kedewasaan seta perubahan perilaku menuju penyempurnaan kehidupan manusia, melalui pembinaan serta pegembangan kepribadiannya. Faktor pendukung kedua adalah akomodasi, keterlibatan psien dalam pengobatan akan meningkatkan partisipasi pasien dalam pengobatan. Faktor ketiga adalah faktor lingkungan sosial dalam bentuk membangun dukungan keluarga. Faktor yang terakhir adalah prubahan model terapi yang mudah dimengerti oleh pasien sehingga mudah untuk dilakukan.

Diet adalah satu cara untuk mengatasi hipertensi tanpa menyebabkan efek yang serius, dengan metode pengendalian yang alami. Banyak orang yang menganggap diet hpertensi meupakan suatu hal yang sulit karena banyak makanan yang harus dihindari. Prinsip yang digunakan dalam diet hipertensi adalah makan makanan gizi seimbang, kemudian sesuaikan kompisisi makanan dengan kondisi penderita serta pembatasan dalam peggunaan jumlah garam (Utami, 2009).

Asupan garam dalam makanan kita relatif banyak dan perlu pengurangan yang diharapkan dapatmenurunkan tekanan darah secara signifikan. Anjuran pengurangan asupan garam yang terbaru adalah sampai di bawah 6 gram per hari (sekitar 1 sendok teh). Kadar garam yang tinggiterdapat dalam sebagian besar makanan yang diproses seperti roti, sereal, makanan siap saji dan saus. Berapa banyak asupan garam yang secara tidak sadar telah kita konsumsi sangat penting untuk kita ketahui. Diet dengan mengkonsumsi makanan tanpa garam disebut diet rendah garam. Dalam proses pembuatan diet rendah garam dimasak tanpa menggunakan garam dapur sama sekali dan mengurangi penggunaanbahan makanan yang tinggi kandungan natriumnya. Sedangkan yang dimaksud dengan diet rendah garam dalam arti yang sebenarnya adalah rendah sodium atau natrium $(\mathrm{Na})$. Diet ini tidak hanya membatasi garam dapur tetapi juga harus membatasi sumber sodium lainnya berupa makanan yang mengandung soda kue, baking powder, MSD (Mono sodium glutamate) atau bumbu penyedap 
makanan, pengawet makanan atau natrium benzoate yang terdapat dalam saus, kecap, selai, jeli dan lainlain), makanan yang terbuat dari mentega, serta obat yang mengandung Na biasanya obat sakit kepala atau obat lainnya (Palmer, 2007).

Menurut Niven (2008), Pendidikan, akomodasi, modifikasi faktor lingkungan dan sosial, perubahan model terapi serta peningkatan interaksi pasien dengan tenaga kesehatan merupakan faktor yang sangat mempengaruhi kepatuhan diet hipertensi. Pendidkan diharapkan dapat mendorong meningkatnya kepatuhan diet hipertensi. Membangun dukungan social dalam keluarga dan teman juga dapat mendukunga terbentuknya perilaku patuh terhadap program pengobatan. Program pengobatan terkait hipertensi sebaiknya dibuat sesedarhan mungkin agar pasien dapat terlibat dalam program tersebut. Peningkatan interaksi tenaga kesehatan dengan pasien merupakan hal yang penting untuk meberikan feedback pada pasien setelah memperoleh informasi tentang diagnosis serta penjelasan mengenai penyakitnya. Baik mengenai penyakit ataupun pengobatan serta peningkatan kepercayaan dari pasien agar mau daang kembali melakukan konsultasi dan selanjutnya meningkatkan kepatuhan diet. Bakri dan Lawrence (2008), mengungkapkan bahwa kepatuhan penatalaksanaan pasien hipertensi memiliki peranan yang sangat penting untuk mengontrol tekanan darah mencegah komplikasi, menurunkan morbiditas dan mortalitas.

Berdasarkan hasil penelitian diperoleh bahwa 70,3\% lansia patuh melakukan diet hipertensi. Menurut Niven (2008), kepatuhan mengacu pada kemampuan untuk mempertahankan program - program yang berkaitan dengan promosi kesehatan, yang sebagian besar ditentukan oleh penyelenggara perawat kesehatan. Faktor-faktor yang mempengaruhi terbentuknya perilaku salah satunya adalah faktor keterbatasan pengetahuan, kesibukan dan faktor lingkungan sehingga mempengaruhi seseorang dalam bertindak termasuk dalam melakukan diet hipertensi (Notoatmodjo, 2012). Faktor lainnya yaitu karakteristik responden sebagai ibu rumah tangga dapat mempengaruhi kemampuan untuk melaksanakan modifikasi diet hipertensi yang tentunya membutuhkan biaya tersendiri. Anggota keluarga tidak membedakan masakan bagi keluarga dan responden adalah salah satu contoh keterbatasan dalam biaya perawatan bagi pasien dalam menjalankan diet hipertensi (Nisfiani, 2014). Berdasarkan hasil penelitian yang dilakukan pada responden kepatuhan dalam pembatasan penggunaan garam (1/2 sendok teh) dalam sehari ketika mengolah makanan untuk lansia termasuk sering dilakukan, dengan dukungan keluarga tersebut maka kepatuhan diet hipertensi pada lansia dikatakan cukup baik.

\section{Hubungan Dukungan Emosional dengan Kepatuhan Diet.}

Dukungan emosional diwujudkan dalam bentuk memberikan makanan khusus kepada responden dengan anggota keluarga dengan harapan tidak mengalami kekambuhan hipertensi sebagai akibat patuh dalam menjalankan program diet hipertensi. Berdasarkan hasil penelitian didapatkan bahwa tidak ada hubungan antara dukungan emosional dengan kepatuhan diet lansia penderita hipertensi. Hal ini disebabkan karena anggota keluarga menjadi kurang berkenan ketika responden makan makanan yang berpatang seperti makanan berlemak sehingga meminta responden untuk segera tidak mengkonsumsi makanan tersebut. Penelitan Rini (2013), menyimpulkan hal yang sama bahwa tidak ada hubungan antara dukungan keluarga dalam bentuk emosional dengan kepatuhan dalam menjalankan diet hipertensi. Hal ini disebabkan adanya faktor lain seperti pengetahuan ataupun sikap penderita hipertensi itu sendiri, kejenuhan serta tidak 
terbiasanya penderita untuk menjalankan diet hipertensi. Pendapat berbeda diungkapkan oleh Nisfiani et. al (2014) bahwa ada hubungan antara dukungan keluarga dengan kepatuhan diet pada usia lanjut dengan $p=0,012$. Semakin baik dukungan emosional yang diberikan oleh keluarga maka dalam menjalankan kepatuhan diet hipertensi semakin baik.

\section{SIMPULAN}

Berdasarkan hasil penelitian diperoleh kesimpulan bahwa sebagian besar responden berjenis perempuan sebesar $54 \%$ yang memilik kriteria umur 60-70 Tahun dengan pekerjaan mayoritas responden adalah Ibu Rumah Tangga dengan tingkat pendidikan lebih dari separuh responden Tamat SMA. Hampir seluruh responden mendapatkan dukungan emosional baik dari keluarga sehingga sebagian responden patuh dalam menjalankan diet namun tidak terdapat hubungan yang signifikan antara dukungan emosinonal dengan kepatuhan diet.

\section{DAFTAR PUSTAKA}

Agrina, R., Hairitama, R., 2011. Kepatuhan Lansia Penderita Hipertensi Dalam Pemenuhan Diet Hipertensi. jurnal keperawatan Community of Publishing in Nursing edisi JanuariApril 2016 [e-journal].

Anggara, FHD.,Prayitno, N. 2013. Faktor faktor yang berhubungan dengan Tekanan Darah Di Puskemas Telaga Murni Cikarang Barat Tahun 2012. Jurnal Ilmiah Kesehatan, 5(1)., Januari 2013.

Aris, S. 2007. Mayo klinik Hipertensi, Mengatasi Tekanan Darah Tinggi. Jakata: PT. Intisari Mediatama.

Bakri, S., Lawrence, G., 2008. Genetika Hipertensi. Medan: USU Press.

Bandiyah.2009. Lanjut Usia dan Keperawatan Gerontik. Yogyakarta: Nuha Medika.
Darmojo,R. Buku Ajar Geriatic (Ilmu Kesehatan Lanjut Usia) Edisi Ke-4. Jakarta: Balai Penerbit FKUI.

Faisal, E., Djarwoto, B., Murtiningsih, B., 2011. Faktor Risiko Hipertensi Pada Wanita Pekerja dengan Peran Ganda Kabupaten Bantul Tahun 2011. Jurnal Berita Kedokteran Masyarakat, Vol.28(2).

Fitriani, A., 2012., Kondisi Sosial Ekonomi dan Stres pada Wanita Hipertensi Anggota Majelis Taklim.Jurnal Kesehatan Masyarakat Nasional, Vol.7(5). https://doi.org/10.21109/kesmas.v7i5 .43

Hamid, S, A. 2013. HubunganPengetahuan dan Sikap KeluargaTentang Pencegahan HipertensiDengan Kejadian Hipertensi. Thesis online.

Hasan, A., 2007. Kamus Besar Bahasa Indonesia. Jakarta: Balai Pustaka.

Irawati, E., Wahyuni., 2011. Gambaran Karakteristik Keluarga Tentang Perilaku Hidup Bersih Dan Sehat Pada Tatanan Rumah Tangga Di Desa Karangasem. Jurnal GASTER vol.8(2).

Jiang, H., 2016. Hypertension in China: a large and increasing public health challenge. Jurnal of Hypertension, Vol.

https://doi.org/10.1097/HJH.0000000 000000818

Murti. B., Rebecca. 2003. Hubungan Antara Tingkat Pendidikan dan Hipertensi Pada Wanita Di Kabupaten Sukoharjo. Jurnal online.

Nina, W. 2007. It's Never Too Late: Physical Activity and Elderly People. Human Kinetics Journals Vol.12(2).

Nisfiani, A., 2014. Hubungan Dukungan Keluarga Dengan Kepatuhan Diet Hipertensi Pada Lanjut Usia Di Desa Begajah Kecamatan Sukoharjo Kabupaten Sukoharjo. Naskah Publikasi.

Niven, N. 2008. Psikologi Kesehatan: Pengantar Untuk Perawat Dan Profesional. Jakarta: EGC. 
Notoatmodjo, S., 2010. Promosi Kesehatan Teori dan Aplikasi. Jakarta: Rineka Cipta.

Notoatmodjo, S., 2012. Promosi Kesehatan dan Perilaku Kesehatan. Jakarta: Rineka Cipta.

Nugroho, W. 2008. Keperawatan Gerontik Edisi 2. Jakarta: EGC.

Nuraini, B. 2015. Risk Factors of Hypertension. Jurnal Majority [ejournal] vol.4(5).

Murdaugh., Pender., 2002. Health Promotion in Nursing Practice. New Jersey: Pearson Education, Inc.

Palmer., W. 2007. Tekanan Darah Tinggi. Jakarta: Elangga.

Peraturan Menteri Kesehatan Republik Indonesia No. 25 Tahun 2016 Tentang Rencana Aksi Nasional Kesehatan Lanjut Usia Tahun 20162019.

Ridwan, M. 2009. Mengenal, Mencegah, Mengatasi Sillent Killer
Hipertensi.Semarang: Pustaka Widyamara.

Rini, S., 2013. Hubungan antara Dukungan Keluarga Terhadap Kepatuhan dalam pembatasan asupan nutrisi dan cairan pada pasien gagal ginjal kronik dengan hemodialisa. Skripsi. Universitas Negeri Riau.

Setiadi., 2008. Konsep \& Keperawatan Keluarga. Yogyakarta: Graha Ilmu.

Tumenggung, I. 2013. Hubungan Dukungan Sosial Keluarga Dengan Kepatuhan Diet Pasien Hipertensi di RSUD Toto Kabila Kabupaten Bone

Utama, P. 2009. Solusi Sehat Mengatasi Hipertensi. Jakarta: Agromeda Pustaka.

World Health Organization (WHO). 2011. Hypertension fact sheet. Departement of Sustainable Development and Health Enviroments.

Zulkifli. 2006. Psikologi Perkembangan. Bandung: PT. Remaja Rosdakarya. 